\title{
Research into the diversification of university careers in learning and teaching and intentionally closing-the-loop on graduate employability
}

James Arvanitakis ${ }^{1}$, Madelaine-Marie Judd ${ }^{2}$, Shelley Kinash ${ }^{3}$, Trina Jorre de st Jorre ${ }^{4}$ and Trish McCluskey ${ }^{5}$

j.arvanitakis@westernsydney.edu.au; m.judd@uq.edu.au; shelley.kinash@usq.edu.au; trina.j@deakin.edu.au; trish.mccluskey@vu.edu.au

Corresponding author: Madelaine-Marie Judd

${ }^{1}$ Pro Vice-Chancellor (Research and Graduate Studies Studies), Western Sydney University, Penrith, Australia ORCID: 0000-0002-7413-0110

${ }^{2}$ Student Partners Advisor, Student Employability Centre, Building 87, The University of Queensland, St Lucia, Queensland, Australia, 4072. ORCID: 0000-0002-5631-1882

${ }^{3}$ Director, Advancement of Learning and Teaching, University of Southern Queensland, Toowoomba, Australia. ORCID: 0000-0002-5631-1882.

${ }^{4}$ Senior Lecturer, Student Achievement, Deakin University, Melbourne, Australia.

ORCID: 0000-0001-7848-0305

${ }^{5}$ Trish McCluskey, Director, Connected Learning, Victoria University.

\begin{abstract}
Universities are both a source of employable graduates and careers. This paper examines universities as developers and employers of their own graduates from the perspective of employees and recruited positions. Research questions were: what do learning and teaching careers look like at universities, and; what are the occupational patterns, satisfactions and concerns of the staff in those careers? An autoethnographic account of employees' career journeys (all of whom were employed in learning and teaching or closely related areas) from five different universities were shared, compared and contrasted. Two of these universities are profiled as having a large proportion of students from target equity groups and therefore have intentionally recruited learning and teaching staff to widen student participation. A desktop review of six months of university employment vacancies from these two universities was conducted. A consistent theme across the autoethnographic stories was a feeling of being an outsider. The authors' hypothesis is that this is related to haphazard preparation for learning and teaching positions. Of the 322 university vacancies, $84 \%$ were for professional staff, $23 \%$ of which were in learning and teaching, with the most prevalent role being Coordinator. Fourteen per cent were for academic staff, $64 \%$ of which involved learning and teaching, and the most prevalent title was Lecturer/Senior Lecturer. Key takeaways include recommendations for universities to intentionally enhance the employability of graduates who pursue learning and teaching positions within universities, and for prospective university learning and teaching staff to enhance their employability.
\end{abstract}

Keywords: graduate employability, careers, universities, higher education, academics, professionals, learning, teaching

Arvanitakis, J., Judd, M-M., Kinash, S., Jorre de st Jorre, T., \& McCluskey, T. (2019) Research into the diversification of university careers in learning and teaching and intentionally closing-the-loop on graduate employability. Journal of Teaching and Learning for Graduate Employability, 10(1), 195-212. 


\section{Introduction}

While one of the primary purposes of higher education is to foster and develop future leaders, universities also serve as large organisations that employ a vast range of staff with unique skills and expertise. In other words, universities serve as gateways to employment and as employers. Recent statistics indicated that over 120,000 staff are formally employed across Australian universities (The Department of Education, 2017). Employment within universities is also the aim of many of our graduates, particularly those completing doctorates, who are often driven by aspirations of a career in research and education.

The size of universities brings complexity, including salient tensions and divides that can be classified as within-role, between-roles and out-of-role (Chubb, Watermeyer, \& Wakeling, 2017; McAlpine \& Åkerlind, 2010; Taylor, 2008). Such tensions are often driven by hierarchies (both real and imagined), that have come to shape the structures and employment within universities.

\section{Within-role tensions}

Within the roles of academics, one of the most talked-about tensions is that of balancing teaching, research and service (Brew, Boud, Lucas, \& Crawford, 2018; Seldin, 2004; Taylor, 2008). Teaching and research have become so polarised, that even 15 years ago, Knight (2002) characterised them as ferrets in a sack (p. 3). Many academics have axiological convictions over whether teaching or researching are nobler roles. While teaching tends to win the social justice competition (i.e. for the good of the students), research-active academics appear to more frequently win the career advancements game, including academic promotions. As such, Seldin (2004) wrote, For years, professors were hired to teach, but were rewarded for research and publication (p. 2). As further testament, academics often use awarded grant money to buy-out their teaching, but it is unheard of to buy-out research. Key evidence of the unequal divide is that when the Australian government abolished the National Office for Learning and Teaching, they simultaneously put more money into research (Kinash, \& Judd, 2018). Brew, Boud, Lucas and Crawford (2018) challenge whether this simple operational definition of academics as teaching and/or research active and accomplished captures the complex nature of these roles.

If teaching and research are the metaphorical ferrets, then service is the sack that should wrap both together, but instead, gets tossed aside. Macfarlane (2007) wrote that service gets forgotten in academe and that a dire consequence is that the fundamental academic role and responsibility - to students - is repositioned as burden rather than mission:

...student service, the most disesteemed element of service, needs to be re-valued both as a moral imperative and as a pragmatic measure to combat the increasing alienation of students in mass systems of modern higher education (p. 6).

What Macfarlane calls 'service' can be conceptualised as the learning function, or in other words, ensuring that universities recognise that student academic success often requires more intervention, than that of traditional teaching activities. For example, Boud and Brew (2013) wrote about the roles of academic developers, in recognition of the need for 'specialist knowledge and skills' to enhance learning processes.

\section{Between-role tensions}

Teaching is one of the key roles and responsibilities of academic staff (Probert, 2013), but many student-directed learning functions are performed by professional staff. The privileging of academic roles within higher education is so pervasive that many universities, and thereby

Arvanitakis, J., Judd, M-M., Kinash, S., Jorre de st Jorre, T., \& McCluskey, T. (2019) Research into the diversification of university careers in learning and teaching and intentionally closing-the-loop on graduate employability. Journal of Teaching and Learning for Graduate Employability, 10(1), 195-212. 
publications, talk about academic and non-academic jobs (Collinson, 2006; McAlpine \& Åkerlind, 2010).

In 2017, academic staff members consisted of 45 percent of Australian university staff, with the other 55 percent classified as non-academic (The Department of Education, 2017). Simply put, more than half of university occupations are reduced to a nomenclature that defines what they are not.

Another common term for these staff is 'professional', but staff in these positions rarely receive the esteem, recognition or status afforded to professionals in other sectors, such as Engineers or Accountants. Furthermore, while the academic voice is robust in the literature, and many articles have been written by and about academic roles, identities and issues, the voice and perspectives of professional staff are rarely heard.

\section{Out-of-role tensions}

Higher education is experiencing workforce transformation, which includes the emergence of a new role, or third space, which might be conceptualised as 'out-of-role', because it does not fit current classifications of academic or non-academic. Whitchurch (2015) describes the third space as those who do not fit conventional binary descriptors such as those enshrined in 'academic' or 'non-academic' employment categories (p. 1). The work that goes on in universities is far more complex than that captured by normative lists of learning and teaching related roles, including, lecturing, facilitating tutorials and labs, giving and marking assignments and tests, timetabling and other administration of these educational tasks. Calling the additional, more hidden, tasks 'backstage work', Knight (2002) listed examples, including, course and programme design, assessment plans, module evaluation arrangements, resource decisions, admissions and teaching policies (p. 1). If an academic role is defined, at least in part, by roles in learning and teaching, then Knight's examples cannot be considered 'non-academic'. Boud and Brew (2013) describe the emergence of a distinct subset of the academic profession (p. 208), academic developers, who may or may not be academics themselves, and whose role it is to support academics to practice learning and teaching.

Increasingly, these 'backstage' roles are conducted by specialised university staff who are not classified as academics, but perform work requiring extensive expertise in learning and teaching. These are not administrative, support or managerial roles. There appears to be no standard or universally-understood classification for this increasingly common positioning, nor empirical work researching this phenomenon. This overlooked and misunderstood identity may contribute to why, authors such as Barnett and Di Napoli (2008), Knight (2002), Macfarlane (2007), Seldin (2004) and Whitchurch (2015) characterise university workforces as troubled and stressful.

Despite these stress-factors, universities continue to attract an abundance of employees, and many staff are compelled to undertake roles for the furtherance of learning and teaching. As expressed by Chubb, Watermeyer, and Wakeling (2017), the emotional ties to academic labour are binding (p. 556). Thus, learning and teaching may explain the preponderance of universities as employers, in that many staff seem to be compelled by what might be called citizen scholarship. Macfarlane (2007) characterised academic citizenship, in part, as to take responsibility for the welfare and development of students, colleagues and fellow professionals (p. 3). Arvanitakis and Hornsby (2016) expanded the notions of citizenship wellbeyond academics to include the broader university (including students). They wrote that a citizen scholar does:

Arvanitakis, J., Judd, M-M., Kinash, S., Jorre de st Jorre, T., \& McCluskey, T. (2019) Research into the diversification of university careers in learning and teaching and intentionally closing-the-loop on graduate employability. Journal of Teaching and Learning for Graduate Employability, 10(1), 195-212. 
...not only care about gaining information and generating knowledge but is also rooted in the reality of their context, problem-oriented and interested in applying their knowledge for the betterment of a society (p. 1).

This description aptly fits university scholars who tirelessly progress excellence in the overall educative experience, regardless of their positioning.

There is a growing body of literature that examines whether academics should be engaged in teaching, research or a combination of the two (e.g. Hajdarpasic, Brew, \& Popenici, 2015). Arguably the most seminal, yet contemporary, discussion paper on the teaching focus of Australian universities was authored by Probert for the Australian Government, Office for Learning and Teaching. Probert (2013) analysed university uptake of teaching-only academic positions, alongside the rationales, emergent benefits and contraindications. Probert wrote that there is increasing differentiation within the academic workforce and one of the driving forces is an explicit desire to raise the status of teaching and develop teaching-focused career paths (p. 2). Notably, Probert's research focuses on one side of two paradigmatic couples in higher education. Whereas the words, teaching and learning are seldom used in isolation in contemporary higher education literature (e.g. Biggs \& Tang, 2011; Ramsden, 2008), Probert's analysis focussed on teaching roles and functions, and did not investigate the counterpart services and supports to assure that students learn. Probert also focussed on the academic career, and did not investigate the role of professional staff in learning and teaching.

Before proceeding, it is important, as authors of this paper, we acknowledge the importance of academic roles, but argue that they are not the defining or pinnacle role or experience of higher education. The argument of this paper is with university careers in the area of learning and teaching becoming increasingly diversified, universities need to implement explicit and targeted strategies for sustaining and developing their own future workforce, especially with respect to roles and pathways in teaching and learning.

\section{Review of empirical studies}

Some empirical studies have investigated the university workforce, but these have primarily focussed on academic roles and perspectives. For example, Acker and Haque (2010) presented a thematic analysis of in-depth interviews with 11 doctoral students nearing dissertation completion and five who had recently graduated, all of whom aspired to be academics. Students and graduates were from the Faculty of Education at a Canadian university. Their comments indicated that they did not have a developed awareness of what an academic career would entail, nor strategic ways and means of building their employability for that career.

Analysis offered two, possibly interactive, reasons for their lack of clarity. First, most students did not have financial independence and needed to balance their survival needs (including working multiple jobs) with degree completion. Second, abstracting from the experiences of students, career supports, strategies and counselling were lacking from the graduate program, including absence from supervisory relationships. Students who were teaching (on a casual basis) appeared to commonly perceive this as just-another-part-time-job and cheap labour for their university, as opposed to offering experiences, apprenticeship and development as future university teachers.

Bosanquet, Mailey, Matthews, and Lodge (2017), situated their research further along the academic career trajectory to early career academics. They analysed five narratives and survey data from 522 early career academics, from three Australian universities, to reconsider current career definitions and classifications. They concluded that the academic workforce is highly variable and characterised by diverse pathways, timeframes and accomplishments.

Arvanitakis, J., Judd, M-M., Kinash, S., Jorre de st Jorre, T., \& McCluskey, T. (2019) Research into the diversification of university careers in learning and teaching and intentionally closing-the-loop on graduate employability. Journal of Teaching and Learning for Graduate Employability, 10(1), 195-212. 
They did not directly address the blurring of academic classification and workload, but acknowledged this as a secondary finding from their research:

The academic role itself is in a state of flux. Traditionally academic work is being reassigned to 'third space' non-academic staff such as learning designers with implications for the scholarly aspects of their work (p. 900).

Notably, these researchers focussed their inquiry on academics and identified others as nonacademic staff.

Clegg (2008) explored the journeys and identities of academics through interviews with 13 academics (7 women, 6 men) at an urban university in the north of England. She sought participation from academics with variable experience (in terms of time) and roles, including those concentrated on teaching and/or research. Academics brought numerous other life roles into the conversation, such as parenthood. Conversations uncovered diverse conflictual spaces (p. 336) such as the oblique nature of university life, as compared to industry, gender and a hierarchy of esteem. Some academics commented that a commonly held perception is that academics are defined by the discipline they teach, but suggested that the role of the academic is far more complex and is actively transforming. Clegg wrote:

...some universities are responding to a more diverse student population, and government policies on employability, by creating courses which cannot be simply defined in terms of discipline or traditional profession. One interesting speculation from the data is that, for some individuals at least, less prestigious places in terms of the league tables of universities might actually allow for the emergence of new, secure, hybridised identities that are not as hampered by the overweening pressure of research productivity (p. 341).

This passage points to variation in pressures and identity influencers based on the ranking of the university's research output. Clegg suggests that the identity of the academic is also influenced by their faculty, school, discipline, and their personal goals. Clegg concluded that the identities of academics are expanding and proliferating and that amidst the change, academics appear able to define themselves, and act in ways that are consistent with their values, including the priority many assign to students and their learning (p. 343).

A final study by Chubb, Watermeyer and Wakeling (2017), was conducted in the context of an impact agenda, broadly defined as a new requirement that academics, with grant-funding, provide evidence of research impact beyond higher education. The researchers used in-depth interviews with mid-career and senior academics (30 in the United Kingdom and 21 in Australia) to investigate how academics 'felt' about the impact agenda. The main finding was that the research participants were highly emotive about their research work and its perceived impact. The authors wrote, For many of our interviewees, impact was seen as critical to their agency and identity; for others, it had the potential to threaten the very nature of what they do (p. 559). Those who expressed the latter perspective tended to talk about managerialism, constraint and loss of trust and power. Inclusion of academics' emotional responses is a strength and unique contribution of this study; however, only academic roles and the research facet of those roles were considered.

This brief review of empirical literature reveals three main gaps: (1) Research appears to focus almost exclusively on academic roles; (2) Methodologies have been only minimally expanded beyond personal stories to include other data sources; and, (3) Research designs have been cross-sectional, as opposed to longitudinal. In order to contribute to resolving these research gaps, this study was designed such that: (1) Positions classified as academic and professional were included; (2) The methodology included personal stories of those working in learning and teaching (or a closely related area) and a high level quantitative dimension was added by analysing university job advertisements; and (3) Personal stories were written in a longitudinal

Arvanitakis, J., Judd, M-M., Kinash, S., Jorre de st Jorre, T., \& McCluskey, T. (2019) Research into the diversification of university careers in learning and teaching and intentionally closing-the-loop on graduate employability. Journal of Teaching and Learning for Graduate Employability, 10(1), 195-212. 
manner, taking career trajectories into account. The two research questions pursued were: (1) What do learning and teaching careers look like at universities, and; (2) What are the occupational patterns, satisfactions and concerns of the staff in those careers?

\section{Research aims and methodology}

This research was designed to empirically investigate the trends, patterns and themes within the context of university learning and teaching (or closely related) roles, from the situated perspectives of employees and recruited positions. Two approaches were taken to investigate the research questions. First, five authors, from different Australian universities, at different phases of their career journeys, wrote narratives depicting their career stories. Authors were invited to tell their stories of university employment, with willing self-consent to vulnerability, and each with an eye to the themes of learning, teaching and research, and of their identities as academic and professional staff. The twists and turns of these stories were then compared and contrasted to reflect-outwards, applying the methodology of autoethnography.

Reed-Danahay (1997), described the essential element of autoethnography as shifting identities, in which the autoethnographer is a boundary-crosser, and the role can be characterized as that of a dual identity (p. 3). As applied to this particular study, the authors are all working in a space between that of academics and professionals, whereby their students are mostly teachers (making them atypical academics) and much of their work is executive leadership and change agentry (their work crosses boundaries, in that much of the content is learning, teaching and research). For boundary crossers (aka: the authors), these conditions create a state that Reed-Danahay described as 'displacement', provoking the authors to inquire into the need for a new category in university employment.

Autoethnography makes three theoretical propositions regarding ontology and epistemology: (1) That group members write their own research stories; (2) That the chosen stories represent the views of contextual minorities, in other words, representing challenging rather than dominant voices; and, (3) That personal reflections and emotional responses are welcomed as part of the text (Reed-Danahay, 1997). In direct application of these propositions to the research presented in this paper: the five authors each wrote their own stories; these particular authors came together, as atypical university employees, in that none progressed through the typical academic pathway (as depicted by Bosanquet, Mailey, Matthews, \& Lodge, 2017); and the authors committed to personal vulnerability through sharing emotionally-laden incidents, as assurance to readers that they are not alone in their confronting experiences.

The first method was an inquiry into what university learning and teaching careers look and feel like for the people in those positions, and the journeys that brought them to this point. The second research method was to broaden the inquiry and look to positions themselves. The selected sample was the full set of university positions advertised (by two of the five universities) across the first six months of 2018. The rationale for choosing the two universities was that both have comparatively high proportions of students from designated equity groups, and have thus put intentional learning and teaching services (and thus positions) in place to achieve widening participation and supporting success. Applying the methodology of manual thematic analysis, a classification grid was created and populated to inquire into: the proportion of academic to professional (or unspecified positions); the extent to which learning and teaching, and conversely research, were key components of the roles; and whether they were short-term contract or continuing positions. As described by Pole and Morrison (2003), this is also a form of ethnography, whereby researchers seek to locate [social] interaction within a wider context which takes account not only of individual agency but also of social structures (p. 47). As such, the authors reached beyond their own stories to investigate some structural indicators of the state of play in regards to universities as employers and university

Arvanitakis, J., Judd, M-M., Kinash, S., Jorre de st Jorre, T., \& McCluskey, T. (2019) Research into the diversification of university careers in learning and teaching and intentionally closing-the-loop on graduate employability. Journal of Teaching and Learning for Graduate Employability, 10(1), 195-212. 
staff as employees. The chosen data set was therefore recent job advertisements to inquire into how universities conduct business as employers.

Analysis of data from both parts of the study was conducted by coding, theming, tabulating, comparing and contrasting. Pole and Morrison (2003) identified the steps of analysis as concurrence, overlaps, sequence, proximity and precedence (p. 95). In alignment with this approach, analysis of the authors' stories inquired into: the parts of the stories that concurred in regard to employment patterns and situations; overlap or commonality, within and between the stories; whether the events happened in similar or different orders for the various authors; how closely each social situation appeared to impact self-identity; and whether the storied events indicated or determined an overall culture. Similarly, these analytic steps informed the unpacking of the job advertisements. Thematic analysis was applied to identifying key words (themes) in the positions' selection criteria, deriving analytic tables for academic and professional positions. Coding was used to reveal trends in response to the research questions (and compared and contrasted with the findings of the reviewed literature). Two of the co-authors separately aggregated and analysed the university job postings. The primary themes (words) they would use for manual analysis were clear and pre-determined. This meant that there was little discrepancy between the two sets of results. Where discrepancy did occur, they discussed the results and made a joint decision. An excel spreadsheet was created, with the top column representing the various coding fields (e.g. learning and teaching, research, role type, contract type, duration) and the rows representing individual advertisements.

\section{Results}

\section{Auto-ethnographical accounts: Our lived experiences}

In the following section, you will encounter five stories - the lived experiences of university staff in various roles at different universities. As articulated by Mills (2010), the changing political economy of academic life becomes meaningful through individual accounts and experiences (p. 74). Three of the stories are told from the perspectives of academic staff who hold PhDs, and two from professional staff, one of whom is in an executive position, and the other of whom is about to undertake a PhD.

\section{From finance to education: The journey of an activist-educator Professor James Arvanitakis}

I am currently the Pro Vice-Chancellor (Research and Graduate Studies) at Western Sydney University. Despite a dozen books (authored and edited) and over 100 publications, I still struggle with the term academic and wrestle with imposter syndrome. I am the first member in my family to attend a higher education institution, and thus lack the university-based cultural capital that many of my contemporaries have always possessed.

My student journey was not smooth through my undergraduate degree. I struggled with what I found to be unclearly defined and unfocussed learning and teaching. I had to come face-toface with the Dean at one point for 'failing too many units'. My postgraduate program in financial markets, on the other hand, helped me to re-imagine and experience what education can be. Those leading the classes were professionals who challenged us to solve the same problems they were confronting. As such, I learned that education could be a living journey, as opposed to dealing with decade-old case studies.

Still, I never intended on being an academic. After completing a science-based degree focussed on economics, I commenced a finance career. I was initially passionate about

Arvanitakis, J., Judd, M-M., Kinash, S., Jorre de st Jorre, T., \& McCluskey, T. (2019) Research into the diversification of university careers in learning and teaching and intentionally closing-the-loop on graduate employability. Journal of Teaching and Learning for Graduate Employability, 10(1), 195-212. 
gathering, interpreting, analysing and curating economic research to assist decision-makers in setting strategy. I liked applying creative skills to unpack the challenges and re-imagine the questions that we, as an economic forecasting and research team, had to confront.

Despite a successful career in finance, I left the sector for personal and professional reasons: the news-stories from the current Royal Commission in the Finance Sector provide some insights into some of the complexities I was dealing with on a personal level.

My 'second career' was working in human rights and environmental justice across Australia, Asia, Europe and the Pacific. Drawing on my financial background, I worked on issues of fair trade, the re-building of post-war economic structures and the politics of foreign aid.

During this time, I also began some additional postgraduate coursework focusing on environmental policy. This experience, combined with a realisation that education is the most powerful tool for both social change and justice, I decided to pursue an emerging interest in becoming an educator - and it was this decision that led me to beginning my PhD. My current research is focussed on cultures of citizenship: understanding why some communities are resilient, active, empowered and engaged, and why others are not. I have translated this into the 'classroom' of the university. All of the innovations I have introduced into curriculum and pedagogy are framed in a philosophy that the education journey should be one of both engagement and empowerment - ensuring our students are active citizens with a sense of control over their lives and the shape of their communities (i.e. citizen scholarship). We must remember that our students do not care about our school, faculty or university organisational chart; they only care about their experience. As educators, it is vital that we make that experience one of learning, curiosity, being challenged, self-identity and empowerment.

\section{Navigating rocky terrains: Madelaine-Marie Judd's journey as a professional educator}

I am currently the Student Partners Adviser at The University of Queensland. I have the opportunity to engage with staff and students from diverse backgrounds who are collaboratively exploring new and innovative ways to enhance curriculum, learning and teaching and the broader student experience.

Long before university, I dreamt about undertaking, and later commenced, a dual degree in Law/Political Science and International Relations. In my first year, I achieved career goal clarity, determining that I did not want to become a lawyer and would drop the law component. I changed universities and degrees, provoking criticism from some family members who said, I would 'never get a job from this degree'. In spite of, and with a fuelled stubborn resolve, I made the change and have not regretted pursuing my passions, as cultural curiosity serves as my constant navigational career force.

I am still not sure whether accident or fate brought me to pedagogical work. My first graduate job as Project Manager of multiple National OLT grants gave me the opportunity to travel throughout Australia and England, meeting passionate fellow staff, students and graduates. The disbanding of the National OLT reinforced my decision to take a job outside of the higher education sector. Beyond that closure, I was dismayed by the confronting experience of nervously moving from contract to contract, with no certainty as to whether the next one would come around. However, by stepping away, I realised how much I loved the higher education sector. I ultimately decided (reminiscent of swapping my university and degree) that I would follow my career passion, knowing that the terrain would continue to be rocky.

I accepted yet another contract in another university's learning and teaching unit. The pressure to produce was immense and the time limits short, but once again I had the opportunity to follow my passions and thereby contribute to university-wide employability. The cycle repeated with yet another restructure. Restructure - adapt - repeat. Despite producing high quality outcomes, developing and fostering collaborations across faculties and central units, and

Arvanitakis, J., Judd, M-M., Kinash, S., Jorre de st Jorre, T., \& McCluskey, T. (2019) Research into the diversification of university careers in learning and teaching and intentionally closing-the-loop on graduate employability. Journal of Teaching and Learning for Graduate Employability, 10(1), 195-212. 
continuing to research and publish in high-ranking journals, I have come to believe that, without the qualifications of $\mathrm{PhD}, \mathrm{I}$ am seen as disposable in uncertain times. Research will not save me as a professional staff member.

At a recent conference, the keynote speaker talked about recurrent patterns of university restructures and the resulting exodus of professional staff members (thought of as expendable and replaceable administrators) through redundancies. Disenchantment with the higher education sector hit me like a fist. I too have encountered these implicit, and at times explicit, attitudinal and structural power and status imbalances between professional and academic staff. I take hope from the many academic educators who do not see these class distinctions, but rather empower those in professional roles. I believe that with time, we will see a new sector era comprised of empowered educators, each with unique experiences and expertise, but there for the common purpose of enhancing the student experience.

\section{An educator from the gut: Professor Shelley Kinash's misunderstood research about learning and teaching}

I am currently Director (Advancement of Learning and Teaching) at the University of Southern Queensland. In Australia, I have directed Learning and Teaching Units, across two universities, for over ten years, which - alongside my Faculty of Education-based experience (mostly in Canada) - adds-up-to over twenty-five years as a university academic. My preuniversity careers were in enabling and supporting inclusion, social justice and community living and contribution for people with disabling conditions. My PhD is in educational technology and my dissertation research was about blind online learners.

I have never liked the term work-life balance, partly because my passion and enthusiasm for most everything I do means that balance is unachievable, but also because I am not happy unless there is work in my life and lots of meaningful life in my work. Part of my life-world is a bad gut which occasionally interferes, in a quite literal way, with my work - such as once, when I had to step-off the stage while giving a keynote address and ask the audience to 'talk amongst themselves' until I arrived back. It also means that I have deeply contemplated what it means to have a gut-level reaction. What matters to me in higher education (from the gut) is that students and staff have a positive experience marked by care - care for, and about, one another, care about learning and knowledge, and care about the world in which we live.

My conviction to excellence in the student learning experience (not only for students at my own University, but across Higher Education), means that learning and teaching is closely aligned-to my value-base and identity. This means that failures and rejections hit hard. Failures are also experientially interwoven with, and exacerbated by, working in the realm of university learning and teaching. For example, for me, academic promotion was not a smooth upward progression to my current classification of Professor. Some panellists argued that because my research was about learning and teaching, it did not count as research. Others argued that because I teach academics, and not traditional university students, my accomplishments did not count as learning and teaching. This has provoked repeated executive discussions about whether I was an academic at all, or should be reclassified as a professional. Furthermore, my research grant success was frequently misunderstood (and reduced) by virtue of the field of research (i.e. education). For example, I led teams to be awarded three national research grants on the topics of graduate employability, student experience and closing-the-loop on student evaluation of courses and teaching. The research grants were classified as Category One and the success rate was 7 percent (applications to awards). In response, multiple colleagues and senior university executives said - now that I had this experience, I could try my hand at applying for a 'real' Australian Research Council (ARC) grant. In other words, the implication is that learning and teaching grants (as applied work) are pilots or practice for worthier research endeavours.

Arvanitakis, J., Judd, M-M., Kinash, S., Jorre de st Jorre, T., \& McCluskey, T. (2019) Research into the diversification of university careers in learning and teaching and intentionally closing-the-loop on graduate employability. Journal of Teaching and Learning for Graduate Employability, 10(1), 195-212. 


\section{A passionate educator: Dr Trina Jorre de St Jorre's haphazard journey from science to education}

I am currently Senior Lecturer (Student Achievement) at Deakin University. My focus is on assuring graduate capabilities, improving the employment outcomes of students and incorporating the student voice into curriculum development. I am grateful to have an academic career and all of the privileges that come with it, although my path here has been a haphazard one.

I was the first person in my family to attend university. School success came easy, so everyone assumed I would do a degree. My favourite subjects were art and literature, but my family encouraged me to pursue a 'safer career path' leading me to a Bachelor of Animal Science. At first, I did not enjoy the degree and became selective about attendance, taking into account factors like subject interest, first impressions of teachers, time of day and ease of parking. A motivational turning-point was a compelling research project, leading to a $\mathrm{PhD}$ in reproductive biology.

I worked throughout and in between both degrees, gaining experience across a wide range of roles and industries: from hospitality to government departments, an automotive collective and the mining industry, to numerous roles at the university itself, including research, administrative and sessional teaching roles. Another turning point, was a postgraduate teaching internship, through which I gained professional development in university teaching, taught and developed curriculum across a wide range of subjects, and completed my first research project in teaching and learning. Most importantly, I was introduced to a valuable mentor, an academic focussed on university teaching and learning, who continues to be an important influence and friend.

When I finished my PhD I was interested in pursuing an academic career, but intent on remaining in my home city. For a while, I accepted sessional and part-time contracts, often concurrently and across different parts of the university. Work was inconsistent and often reduced between teaching periods. I often worked beyond paid hours to meet the needs of my students.

Feeling undervalued, and knowing that sessional teaching rarely leads to an academic career, I left the university sector to pursue more regular hours and income. Working for large organisations in different sectors (especially the mining industry) was an invaluable experience - teaching me new skills, but more importantly, confirming the career paths I did not want to follow. So when I was offered the consistent hours and stability I had been seeking, I instead accepted a two month contract at a university teaching and learning centre. This led to further work and opportunities to collaborate with learning and teaching leaders across Australia. Equally enjoyable, was the opportunity to contribute to the support and development of emerging academics and sessional teachers. When the centre was restructured, I made a conscious decision to seek positions in teaching and learning instead of science, leading me to my current career. I still love science, and enjoy opportunities to work with science faculties to improve undergraduate learning experiences, but have no regrets about ending up where I am now, or the haphazard pathway that got me here.

\section{Journey of an accidental educator: Trish McCluskey}

My current position is Director (Connected Learning) at Victoria University. I am fortunate to lead a team of 40 staff who are all engaged and passionate about supporting learning and teaching design. Most are employed as professional staff and all have postgraduate qualifications, including PhDs.

I have a pervasive secret angst about getting found out - specifically about people discovering that I really do not belong. My culturally ascribed belief that 'people like me' do not usually

Arvanitakis, J., Judd, M-M., Kinash, S., Jorre de st Jorre, T., \& McCluskey, T. (2019) Research into the diversification of university careers in learning and teaching and intentionally closing-the-loop on graduate employability. Journal of Teaching and Learning for Graduate Employability, 10(1), 195-212. 
achieve this level of career success is ingrained in my psyche. As an Irish Catholic, growing up in the 1970s in the troubled borderlands of Northern Ireland, my expected life trajectory was to leave school, work in the domestic/secretarial/service sector for a few years, then get married, have the obligatory dozen kids and live happily ever after in domestic, family and community servitude.

I applied for every job and apprenticeship in the newspaper and finally got accepted into a nursing school in Belfast. Big city, bright lights, bombs and riots, were just what I needed to launch me into an alternative reality and possible future. After a couple of years, this led to an opportunity to move to New Zealand with the promise of a one year all expenses paid nursing contract. I never used the return ticket.

While undertaking a Health Management course at my local university, I was invited to apply for a teaching position. I raided the library shelves to find books on how to teach and discovered Carl Rogers, who outlined principles of learning that have shaped my practice in teaching and management ever since. I found particular resonance with his propositions of having unconditional positive regard for students and creating meaningful learning experiences. While teaching nursing, I pursued part-time studies towards an undergraduate degree in education and came to understand the cultural and institutional barriers that had prevented me from attending university earlier in my life. I am now a passionate advocate of open access to education for everyone, regardless of their background. I subsequently completed a Master's Degree in Education and have dropped in and out of PhD studies which I might one day get around to completing.

I moved to Melbourne in 2003 and since that time have worked in both the TAFE and Higher Education sectors, across a range of professional and academic roles including, Chair of Academic Board, University Council member and the Director of a Learning and Teaching Centre. I have been able to successfully navigate the many structural barriers and interprofessional dynamics and tensions that exist in tertiary education in Australia. However, I believe the time is right to evolve a new classification of Higher Education worker who is recognised for their learning and teaching design expertise. My university is currently exploring the creation of such a role and having it recognised in the enterprise agreement.

\section{Job advertisement classification}

The second approach informing this paper was an analysis of 322 job advertisements, representing all jobs posted by two Australian universities over a six-month period. In total, 84 percent (270 positions) of the positions advertised were for professional staff, in contrast to 14 percent (44 positions) for academic staff. Two percent (8 positions) of the advertisements were for executive staff, with one advertisement for a Research Assistant.

Each of the job postings were analysed to identify the occurrence of learning or teaching (combined), and research, as components of positions. As depicted in Figure 1, 64 percent of academic roles included components of learning and teaching. This contrasted with 23 percent of professional roles. A greater divide was evidenced with respect to research, with 79 percent of academic roles including research as a component of the role, versus 7 percent for professional positions.

Arvanitakis, J., Judd, M-M., Kinash, S., Jorre de st Jorre, T., \& McCluskey, T. (2019) Research into the diversification of university careers in learning and teaching and intentionally closing-the-loop on graduate employability. Journal of Teaching and Learning for Graduate Employability, 10(1), 195-212. 


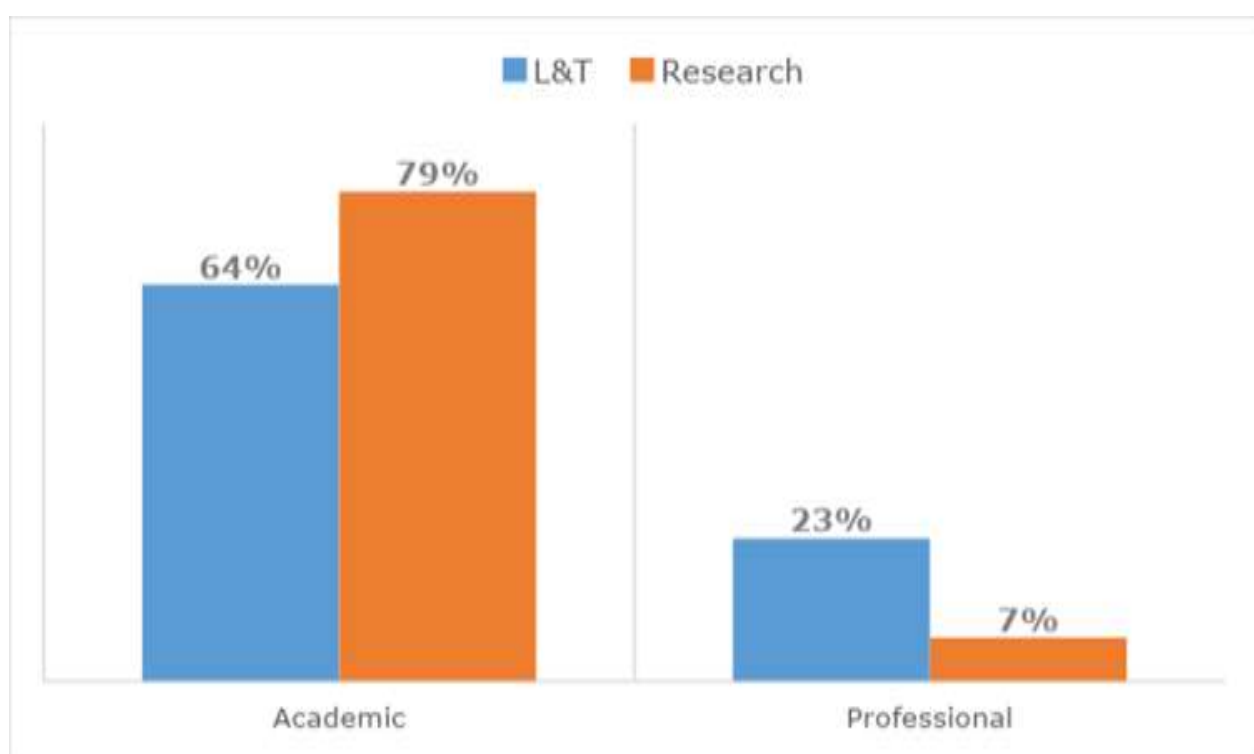

Figure 1: Percentage of Academic and Professional Roles that Include Learning and Teaching or Research.

Analysis of position titles revealed that the most common title of academic positions was Lecturer / Senior Lecturer (indicating the most common entry route into academic streams), and that the most common title of professional positions was Coordinator (sometimes, but not always in roles and teams related to learning and teaching).

Further analysis of the selection criteria for position descriptions found 119 unique requirements for Professional Staff and 100 criteria for Academic Staff. Among selection criteria for Professional staff positions, 'managing' and 'communicate' were the most frequently appearing terms, contrasting with 'research' and 'collaborative' for Academic positions. Of significance, 12 of the top 20 criteria appeared across both Professional and Academic Staff classification types, indicating common skill sets required for both roles.

The final element addressed in this classification was duration of contract (i.e. fixed term or continuing appointment). Approximately half of both academic and professional roles were continuing (50 percent and 51 percent respectively). Of the academic positions that were not continuing, the average duration was 3 years. The modal duration was 3.5 years. The average duration of the professional positions was 1.5 years. The modal duration was 6 months.

\section{Discussion}

A key theme emerging across all author depictions was the sense of feeling like an imposter and not quite belonging. This was presented in different ways, but each author struggled with their journey, their titles and their fit within university culture. Each authoethnographic authors' interweaving of an outsider characterisation with a haphazard journey to a university career in learning and teaching (or closely related area) led the authors to hypothesise that these two facets of the stories were interrelated. In other words, the authors hypothesised (for further research) that if universities provided intentional and strategic pathways and graduate employability supports for university learning and teaching careers, people in these careers would feel better prepared, established and credentialed.

A second recurrent theme was that despite the broad-based perspective on careers, the authors all described being deeply impacted by people, experiences, attitudes, culture and context beyond the workplace. It appears that these backgrounds can also lead to insecurities and feeling like an outsider. In spite of the haphazard and sometimes uncertain nature of

Arvanitakis, J., Judd, M-M., Kinash, S., Jorre de st Jorre, T., \& McCluskey, T. (2019) Research into the diversification of university careers in learning and teaching and intentionally closing-the-loop on graduate employability. Journal of Teaching and Learning for Graduate Employability, 10(1), 195-212. 
university careers, each author described finding themselves (mostly) happily engaged at universities - grateful for the ability to contribute to the learning and teaching environment, and for having a part in the impact that higher education can have on the lives of students and graduates.

Six propositions about university staff, working in the area of learning and teaching (or closely related areas), can be extrapolated from the narratives of the five authors.

1. Passionate educators have a well-defined philosophy of learning and teaching and refuse to act in ways that contravene their value-driven principles.

2. There are valid and fulfilling pedagogical roles beyond university faculties.

3. Boundaries blur and overlap between the categories of: (a) learning and teaching, (b) research, and (c) service. The total of the whole educator role is greater than the sum of its parts.

4. Universities can provide diverse opportunities for fulfilling, high-impact work.

5. Career trajectories, within higher education, are seldom linear and structured. Instead, they are marked and altered by critical incidents, and they loop, tangle and vary.

6. Self-doubt, fraught relationships and the continual need for reflection and prioritisation do not decrease (and perhaps increase) as one moves up the higher education career ladder.

These propositions were reconsidered alongside the thematic clustering of terms used in the selection criteria from advertised university vacancies. Only the propositions that were directly supported, or disputed, by the classification data were included below.

1. The words 'teaching and learning' occurred as a sub-theme (indicating that only some selection criteria included these words) in academic position descriptions. This may indicate that this is an assumed, rather than explicitly highlighted role in higher education. The words 'teaching and learning' were not a prevalent theme across the selection criteria of professional positions. This may indicate that higher education, as a sector, has not reflected on, and explicitly mapped the growing role (and selection criteria) of professional staff in learning and teaching.

2. The word 'research' was the most common theme across the academic positions. This confronting finding indicates that 'research' skills and experience continue to be the highest sought selection criteria across the analysed academic positions. This is particularly notable in the context of the point above, that 'teaching and learning' was a small sub-theme in academic positions and did not frequently appear in the selection criteria of professional positions. This is also despite neither of the universities examined being profiled as research-intensive institutions. This finding appears to further support the proposition that universities continue to prioritise research over learning and teaching.

3. The word 'managing' ties for the largest theme (alongside 'communicate') across professional selection criteria. This indicates that universities have numerous management positions, and that these positions are usually classified as professional.

4. The word 'PhD' is the third largest theme (after 'research' and 'collaborative') across academic selection criteria. This reinforces the autoethnographic comments of this paper's authors that PhDs are high collateral for university employment (in this case, for academic positions).

Arvanitakis, J., Judd, M-M., Kinash, S., Jorre de st Jorre, T., \& McCluskey, T. (2019) Research into the diversification of university careers in learning and teaching and intentionally closing-the-loop on graduate employability. Journal of Teaching and Learning for Graduate Employability, 10(1), 195-212. 


\section{Findings}

This section of the paper specifically summarises responses to the two research questions, as informed by the results of this study, alongside findings from the reviewed literature.

\section{What do learning and teaching careers look like at universities?}

It is no wonder that the doctoral students in Acker and Haque's (2010) research had only the vaguest idea about what a university career would look like. Both the autoethnographic descriptions and job analysis data confirmed that learning and teaching careers are diverse and highly variable. This concurs with previous work by Bosanquet, Mailey, Matthews and Lodge (2017). Another finding also noted by these authors, is that learning and teaching roles and responsibilities are increasingly being managed and conducted by university staff in nonacademic roles. It is therefore not a given that universities assign, nor staff look to, academic roles in order to play a significant role in advancing student learning, and in significant related functions such as fostering graduate employability.

\section{What are the occupational patterns, satisfactions and concerns of the staff in these careers?}

The research of Clegg (2008) and Chubb, Watermeyer and Wakeling (2017) emphasised that identities and career trajectories of academics are complex and often vexed, but at the same time, value-driven. Furthermore, academics and their identities are impacted by the changing nature of universities. The research presented in this paper confirms these findings, and notably adds that this is also true of non-academic staff in learning and teaching (and closely related) roles.

\section{Implications}

\section{How universities can improve graduate employability for university learning and teaching positions}

A common thread amongst the personal accounts, was that each author talked about education, learning and teaching as an opportunity, with the potential to transform lives. However, all of the authors also describe risk and struggles; their pathways were not easy or straight-forward.

As a result, the following recommendations are made to universities as future employers of their graduates. In other words, these recommendations are for improving graduate employability for learning and teaching positions:

1. Create a map of human resources to assure that learning and teaching needs match the positioning of jobs, in situated cultural contexts.

2. Increase the explicit and transparent identification of career opportunities, selection criteria, and promotional or developmental pathways.

3. Move beyond a simplistic nomenclature of careers into academic versus nonacademic. Consider the inclusion of additional categories into human resource position classifications (which move beyond the binary classification of positions into academic and non-academic).

4. Design graduate apprenticeships, formal learning and teaching inductions, and structured mentorships to develop and sustain the future higher education workforce in the context of learning and teaching.

Arvanitakis, J., Judd, M-M., Kinash, S., Jorre de st Jorre, T., \& McCluskey, T. (2019) Research into the diversification of university careers in learning and teaching and intentionally closing-the-loop on graduate employability. Journal of Teaching and Learning for Graduate Employability, 10(1), 195-212. 


\section{How students and graduates can improve their own employability for university learning and teaching positions}

The following recommendations are for existing university staff or those aspiring to university careers in learning and teaching, as informed by the authors' lived experiences.

1. Reflect on the journey, culture and context that brought you to this current place in your career. Consider and rise above self-imposed limits. Pursue your passions.

2. Do not pitch yourself too narrowly. There are a diverse range of career options in higher education, and multiple means of attaining and demonstrating your match with selection criteria.

3. Do not restrict yourself to either academic or professional positions in that there is a large degree of overlap between these positions and rewarding careers in both.

4. If you are passionate about learning and teaching, develop your skill sets in the associated roles and responsibilities. This is a growing domain, and thereby source, of fulfilling university careers.

5. Allow yourself to explore, discover and learn throughout your university career journey. Be open to new possibilities and opportunities.

6. Read broadly, understand and articulate your philosophy of learning and teaching and share your distinctive value-proposition and personal brand in higher education.

7. Be discriminating in where you extend your efforts and energies. Choose the initiatives, the colleagues, and the research endeavours that will have the most impact on students, graduates and our overall world.

\section{Conclusion}

Universities are major and diverse employers. Analysis of job vacancies from two Australian universities indicated that career opportunities are numerous and varied. However, developmental and transitional support for learning and teaching positions appears to be ad hoc, accidental and piecemeal, as opposed to strategic, transparent, and aligned with ontological, epistemological and axiological propositions. This means that there are seldom cohesive and efficacious strategies to ensure that graduates are employable within universities. Universities appear to reactively create new positions as department needs arise, or fill vacant positions without strategic purpose, without consideration of career gateways or pathways.

The current primary nomenclature of positions is a simplistic division into academic and nonacademic, but this structure no longer appears to be functional, and limits opportunities for graduates. Across 322 advertised positions, 84 percent were classified as non-academic (mostly called professional). Within these positions, 23 percent explicitly included learning and teaching functions, and 7 percent identified research obligations. By current working definitions, these positions should be classified as academic. The learning and teaching functions of universities have become sophisticated and complex, requiring specialised expertise beyond lecturing. This study provided introductory evidence that at least some elements of the treatment of academic and professional staff are equivalent, in that 50 per cent of jobs in both categories were continuing. However, of the academic positions that were not continuing, the average and modal duration were 3 and 3.5 years respectively. The contractual terms were much worse for professional staff at 1.5 years and 6 months respectively.

Arvanitakis, J., Judd, M-M., Kinash, S., Jorre de st Jorre, T., \& McCluskey, T. (2019) Research into the diversification of university careers in learning and teaching and intentionally closing-the-loop on graduate employability. Journal of Teaching and Learning for Graduate Employability, 10(1), 195-212. 
The stories of the five authors (all of whom are university graduates and working within different universities), confirmed the findings of the job analysis. All five made their way to their current careers through tangled webs of incremental experiences. None had experienced structured, intentional strategies to prepare them for university employment, such as career apprenticeships or progressive ladders. All five experienced (and continue to experience) angst as to their personal places. However, all also remain committed and passionate, experiencing university work as a calling, motivated primarily by a love for learning and students. The authors do not wish to diminish the importance of personal learning journeys and career-oriented agency: they are unanimous in the belief that universities would thrive through a more coherent, transparent and supportive human resource system and employment strategy that specifically addresses learning and teaching.

The main contribution of this paper is providing evidence for the proposition that the explicit identification of themes has the potential to move universities from a human resource process that is ad hoc and mostly considers one position at a time, to a strategy that creates the momentum to enact each university's mission and goals. This has the potential to achieve intentional, purposeful hires and efficacious university graduate employability supports for our own industry. The main limitation of this study was that only the job advertisements of two universities were analysed, thus limiting the sample size and diversity. A recommendation for future research is to analyse a larger sample size of advertisements across university-type. Furthermore, it is recommended that the analysis of university positions is expanded to include other indicators that focus on learning, such as the words students and enabling. 


\section{References}

Acker, S., \& Haque, E. (2010). Doctoral students and a future in academe? In L. McAlpine \& G. Åkerlind (Eds), Becoming an academic: International perspectives (pp. 96-124). London: Palgrave Macmillan.

Arvanitakis, J., \& Hornsby, D.J. (2016). Universities, the citizen scholar and the future of higher education. London: Palgrave Macmillan.

Barnett, R., \& Di Napoli, R. (2008). Changing identities in higher education: Voicing perspectives. Abingdon, Oxon: Routledge.

Biggs, J., \& Tang, C. (2011). Teaching for quality learning at university: What the student does, $4^{\text {th }}$ ed. Berkshire, England: Open University Press.

Boud, D., \& Brew, A. (2013). Reconceptualising academic work as professional practice: Implications for academic development. International Journal for Academic Development, 18(3), 208-221. doi:10.1080/1360144X.2012.671771

Bosanquet, A., Mailey, A., Matthews, K.E., \& Lodge, J.M. (2017). Redefining 'early career' in academia: A collective narrative approach. Higher Education Research \& Development, 36(5), 890-902. doi:10.1080/07294360.2016.1263934

Brew, A., Boud, D., Lucas, L., \& Crawford, K. (2018). Academic artisans in the research university. Higher Education, 76, 115-127. doi:10.1007/s10734-017-0200-7

Chubb, J., Watermeyer, R., \& Wakeling, P. (2017). Fear and loathing in the academy? The role of emotion in response to an impact agenda in the UK and Australia. Higher Education Research \& Development, 36(3), 555-568. doi:10.1080/07294360.2017.1288709

Clegg, S. (2008). Academic identities under threat? British Educational Research Journal, 34(3), 329-345. doi:10.1080/01411920701532269

Collinson, J.A. (2006). Just 'non-academics'? Research administrators and contested occupational identity. Work, Employment and Society, 20(2), 267-288. doi:10.1177/09500170060641

Hajdarpasic, A., Brew, A., \& Popenici, S. (2015). The contribution of academics' engagement in research to undergraduate education. Studies in Higher Education, 40(4), 644-657. doi:10.1080/03075079.2013.842215

Kinash, S., \& Judd, M-M. (2018, July). What's hot \& what's not in the strategic plans of Australia's universities. Published peer-reviewed conference proceedings from HERDSA 2018, 2-5 July, Adelaide, South Australia.

Knight, P.T. (2002). Being a teacher in higher education. Ballmoor, Buckingham: Open University Press.

Macfarlane, B. (2007). The academic citizen: The virtue of service in university life. Abingdon, Oxon: Routledge.

McAlpine, L., \& Åkerlind, G. (2010). Becoming an academic: International perspectives. New York, USA: Palgrave Macmillan.

Mills, D. (2010). Employment patterns in and beyond one's discipline. In L. McAlpine \& G. Akerlind (Eds), Becoming an academic: International perspectives (pp.71-95). London: Palgrave Macmillion.

Pole, C., \& Morrison, M. (2003). Ethnography for education. Berkshire, England: McGraw-Hill.

Probert, B. (2013). Teaching focused academic appointments in Australian universities: recognition, specialisation or stratification? Sydney, NSW: Office for Learning \& Teaching.

Ramsden, P. (2008). Learning to teach in higher education, $2^{\text {nd }}$ ed. Abingdon, Oxon: Routledge Falmer.

Reed-Danahay, D. (1997). Auto/Ethnography: Rewriting the self and the social. Oxford, UK: Berg.

Seldin, P. (2004). The teaching portfolio: A practical guide to improved performance and promotion/tenure decisions, 3rd ed. Pleasantville, NY: Anker.

Taylor, P. (2008). Being an academic today. In R. Barnett, \& R. Di Napoli (Eds.), Changing identities in higher education: Voicing perspectives (pp.27-39). Abingdon, Oxon: Routledge.

Arvanitakis, J., Judd, M-M., Kinash, S., Jorre de st Jorre, T., \& McCluskey, T. (2019) Research into the diversification of university careers in learning and teaching and intentionally closing-the-loop on graduate employability. Journal of Teaching and Learning for Graduate Employability, 10(1), 195-212. 
The Department of Education. (2017, 15 December). 2017 Staff Numbers. Retrieved from https://docs.education.gov.au/node/46141

Whitchurch, C. (2015). The rise of third space professionals: Paradoxes and dilemmas. In U. Teichler \& W.K. Cummings (Eds), Forming, recruiting and managing the academic profession (79-99). Dordrecht: Springer. 